\title{
아프가니스탄 재건을 위한 한국정부의 원조
}

유 영 방 / 전 아프가니스탄 대사

\section{1. 원조의 배경 및 과정}

\section{가. 미국의 대테러전과 아프간 임시정부 수립}

아프가니스탄은 1979 년 12 월에 시작된 소련의 침공으로 약 10 년에 걸쳐 전쟁을 수행했고 1989 년 2월 소련군이 철수를 완료한 후에도 국내 정파 간의 투쟁으로 내전을 경험하게 되었다. 내전 기 간 중 가장 혹독했던 1994 년부터 1년 동안 약 25 천명이 사망한 것으로 추정되며 수도 카불의 $1 / 3$ 이 파괴되는 비극을 맞기도 했다. 내전 기간 중 새 로운 세력으로 부상한 탈레반이 1996년 9월 수도 카불을 점령함에 따라 동 기간부터 2001년 11월 미국의 대아프가니스탄 테러전으로 탈레반 정권 이 붕괴될 때까지 아프간 국민들은 약 22 년에 걸 쳐, 전쟁과 폭력으로 말할 수 없는 고통을 겪었다. 탈레반은 1997년 국호를 Islamic Emirate of Afghanistan으로 바꾸고 이슬람 율법을 시행하
였으며 이에 따라 여성은 의료행위 외의 직업 및 사회활동을 할 수 없게 되고 율법 위반자에 대한 체형이 도입되었다. 이슬람 율법의 왜곡 및 철저 한 시행으로 아프간 국민들은 전쟁이상의 고통을 겪게 되었다. 전쟁으로 국토가 폐허로 바뀐 상황 속에 무자비한 인권탄압으로 사람들은 전쟁이 끝 난 후에도 가난과 육체적, 정신적 고통 속에 다수 가 인접국 등 제 3 국에서 난민생활을 계속하고 있 었다.

2001년 9/11 테러사건 이후 미국은 탈레반정부 에 당시 아프가니스탄에 체류중인 것으로 알려졌 으며 테러 주범으로 지목된 알카에다 지도자를 인 도 요청하였으며 탈레반 정부가 이를 이행하지 않 자 동년 11월 대 아프가니스탄 테러전을 감행하게 됨에 따라 탈레반 정권은 종말을 맞게 되었다.

탈레반 정권이 축출된 후 미국을 비롯한 국제사 회는 아프가니스탄에 평화를 정착시키고 새로운 국가 건설과 경제 및 사회 재건을 위한 노력에 착 
수하게 되는데 이를 위한 일차적인 노력으로서 유 엔안보리의 조치를 들 수 있다.

2001년 11월 14일에 채택된 안보리 결의안 (1378)의 주요내용은 첫째, 아프간에서 테러리즘 을 뿌리 뽑기 위한 국제사회의 노력을 지지하고 유 엔 사무총장의 특별대표가 제안한 아프간 평화절 차와 관련 아프간 제 정파 간 회합소집 계획을 환 영하고 둘째, 아프간 국민의 새로운 과도정부 수립 노력을 지지하고 아프간군의 보복행위 자제를 요 청하는 한편 아프간 국민들의 과도정부수립을 지 원함에 있어 유엔이 중심적 역할을 해야 함을 확인 하고 셋째, 유엔회원국들이 조속히 효과를 볼 수 있는 프로젝트(quick-impact projects)의 이행을 포함 아프간 과도정부를 지원할 것과 아프간 국내 외의 난민에 대한 긴급 인도적 원조를 시행하며 지 뢰제거를 포함하여 아프간의 경제 및 사회재건을 위한 장기지원을 요청하며 넷째, 아프간이 더 이 상 탈레반의 치하에 들어가지 않도록 안전을 확보 하도록 지원을 권장하고 있다.

동 결의안은 아프간의 새로운 과도정부 수립을 위해 유엔의 중심적 역할을 강조함으로써 특히 외 세의 침입에 시달려 온 아프간 국민들의 의혹을 줄 이고 협력을 이끌어 낼 수 있는 계기를 마련한 것 으로 볼 수 있다.

이어 유엔은 안보리결의안 1378 을 이행하기 위 한 조치로서 아프가니스탄에 새로운 민주정권이 확립될 때 까지 운영될 임시통치기구 구성을 위한 아프간 주요 4 개 정치적 이익집단이 참여한 회의 를 2001.11.27 12.5 간 독일의 본에서 개최하였
다. 회의에 참석한 아프간의 각 계 대표들은 임시 통치기구(Afghan Interim Authority) 구성에 합 의하고 신헌법제정을 위한 제헌의회 소집을 요청 하는 "본 합의서"( Bonn Agreement)에 서명하였 는데 동 임시통치기구는 임시행정부, 긴급제헌의 회 소집 특별위원회 및 대법원 등 3 부로 구성되어 아프간의 새로운 민주적인 정권 창출을 향한 기반 이 되었다.

\section{나. 아프가니스탄 재건을 위한 국제사회의 노력}

\section{1) 아프가니스탄 재건지원에 관한 고위급회담}

유엔안보리 결의안(1378) 이행을 위해 미국과 일본이 주최한 한국을 포함한 세계 주요 21 개 국가 및 국제기구가 참여한 고위급 회담이 2001년 11월 27일 미국 워싱턴에서 개최되었다. 주요 참가국가 로는 G8 회원국, 화란, 스웨덴, 덴마크, 사우디, 터 키, 한국, 중국, 인도, 스위스, 호주, 핀란드, 오지 리, 노르웨이며 국제기구로서는 UNDP, OCHA, $\mathrm{UNICEF}, \mathrm{WFP}, \mathrm{UNHCR}$ 등이며 그 외 $\mathrm{EU}$, $\mathrm{OIC}$ (의장국인 카탈), $\mathrm{WB}$ 와 $\mathrm{ADB}$ 가 참가했다.

이 회의에서는 유엔의 중심적 역할, 국제사회의 대 아프가니스탄 재건지원, 인도적 지원과 재건지 원 간에 긴밀한 연계, 아프간 국민의 적극적인 참 여, 지원 참가국 및 국제기구 간 활동에 있어 조정 의 필요성, 지원활동 참가자에 대한 안전 확보 및 원조이행 계획의 신축성 등 제반 원칙을 제시하는 한편 다음과 같은 후속조치에 합의했다. 
1) 정책적 가이드라인 제시를 위한 회의개최에 대비, 일본, 미국, $\mathrm{EU}$ 및 사우디로 구성하는 운영위원회를 구성

2) 제 1차 운영위원회를 2001년 12 월중 유럽에 서 개최

3) 2002. 1 각료급회의를 일본에서 개최

4) $\mathrm{WB}, \mathrm{UNDP}$ 및 아시아개발은행에 각료급회 의에 보고될 포괄적인 원조수요 평가 보고서 준비를 요청

5) 동년 11.27-29간 $\mathrm{WB}, \mathrm{UNDP}$ 및 $\mathrm{ADB} 3$ 자간 의 회의를 거쳐 아프간지원그룹(ASG)회의를 $12.5 \sim 7$ 간 개최하기로 합의

\section{2) 아프가니스탄 재건지원 도쿄 각료급회의}

아프간 재건지원에 관한 워싱턴회의(고위급 회 의) 합의에 따라 일본, 미국, $\mathrm{EU}$ 및 사우디아라비 아 대표를 공동의장으로 한 아프간 재건지원을 위 한 각료급회의가 일본 도쿄에서 2001년 1월 21 22 간 개최되었다. 동 회의기간에는 국제 $\mathrm{NGO}$ 회의도 개최되었으며 국제 $\mathrm{NGO}$ 를 통한 협 력방안도 논의되었다.

동 회의에 한국을 포함한 61 개국 및 21 개의 주 요 국제기구 및 $\mathrm{EU}$ 대표가 참석하였으며 참가국 대표들은 아프간의 평화와 안전을 지원함은 물론 경제 및 사회재건을 지원할 것을 약속하였다. 우리 정부는 한승수 외교통상부장관을 단장으로 한 대 표단을 파견하였다.

협의 초점은 참가국들이 아프간 재건지원에 관 한 구체적 내용을 포함한 정치적 메시지를 발표하
고 아프간의 제 정파 간에 합의를 본 본 합의서 (Bonn Agreement)에서 규정한 평화의 절차 (Peace Process)를 이행할 것과 대의제도를 확립 하며 테러와 아편재매 및 마약거래를 근절하는데 협력할 것을 재건지원의 조건으로 내세웠다.

한편 아프간 과도정부는 동 회의에서 국제사회 의 재건지원 우선사업으로서 아래와 같은 분야를 제시하고 국제사회의 지원을 요청하였다.

1. 공무원 보수지급과 정부행정 제도의 확립 등 행정능력 강화

2. 교육, 특히 여성교육

3. 보건 및 공중 보건

4. 도로, 전기 및 통신 분야에 있어서 인프라 개발

5. 통화제도를 포함한 경제제도의 재건

6. 식량안보, 수자원 관리 및 관개시설을 포함한 농업 및 지역개발

도쿄회의를 통해 참가국과 국제기구들은 우선 2002 년 중에 18 억불 규모의 원조를 시행할 것과 이를 포함 향후 3 년에 걸쳐 총 45 억불을 지원하겠 다는 서약을 하였으며 주요 서약내용은 일본이 2.5년간 5 억불, 미국이 2002년 중 290백만불, 사우디가 3 년에 걸쳐 220 백만불, $\mathrm{EU}$ 가 2002년에 5 억불( $\mathrm{EC}$ 는 5 년에 걸쳐 십억 유로)을 지원할 것을 발표하였다. 우리 정부는 2002 2004년에 걸쳐 45 백만불(전체 서약규모의 약 $1 \%)$ 을 지원할 것을 서약하였다. 


\section{3) 아프간 재건지원을 위한 베를린 각료급회의}

2004년 $3.31 \sim 4.1$ 간 베를린에서 독일 및 아 프간 정부와 유엔이 공동 주최한 아프간지원을 위 한 각료급회의가 열렸다. 동 회의에는 65 개 국가 및 국제기구 대표들이 참석하였으며 우리정부는 황두연 통상교섭본부장을 단장으로 한 대표단을 파견하였다.

동 회의에서 특히 국제치안지원군(ISAF)의 계속 적인 주둔, 군과 민간인으로 구성된 지방개발팀 (PRT)의 지방에 대한 치안유지 활동 및 재건과 개 발노력 지원, 2004. 6월 말까지를 시한으로 한 제 1 단계 무장해제 $(\mathrm{DDR})$ 계획의 이행, 아프간 군과 경 찰을 강화하고, 마약으로부터의 위협을 제거하는 등 치안유지 및 재건에 대한 구체적인 내용에 대해 국제사회가 공동의 노력을 기울이기로 합의하였다.

특히 지방의 치안유지와 동시에 개발을 지원하 기 위해 국제사회가 최초로 시도하는 PRT 활동을 $\mathrm{NATO}$ 주관하에 지방으로 점차 확대해 나가고 아 편재배의 근절과 마약의 불법생산 및 유통을 방지 하기 위한 노력을 강조하였다.

참석 대표들은 2004 6년간 82억불의 원조를 공여하기로 서약하였으며 그 중 44억불을 2004년 에 지원하기로 하였으나 우리 정부는 구체적인 금 액을 밝히지는 않고 아프간에 계속적인 지원을 하 겠다는 약속을 하였다.

\section{4) 아프가니스탄 재건지원을 위한 런던 각료급회의}

2006.1.31 2.1간 런던에서 영국과 아프간 정부 및 유엔이 공동개최한 각료급 아프간 원조국회의
가 개최되었다. 우리 정부는 반기문 외교통상부 장 관을 단장으로 한 대표단을 파견하였으며 반기문 장관은 회의 참석 외에 동 회의에 참석한 Hamid Karzai 아프간 대통령과 면담, 양국간 협력방안에 관한 의견을 교환하였다.

런던회의에서는 "본 합의서", 도쿄 원조국회의 및 베를린 원조국회의를 통해 아프간에 지원한 원 조의 경험을 토대로 아프가니스탄을 보다 장기적 으로 안정화하고 경제 사회개발을 지원하기 위한 접근방법을 취한데 그 특징이 있다. 이를 위해 아 프간 정부와 국제사회는 아프간정부의 "새천년 개 발목표"(Afghanistan Millennium Development Goals Country Report 2005, Vision 2020) 를 달성하기 위한 “아프간 국가개발 전략" (the Afghanistan National Development Strategy :ANDS)에서 밝힌 아프간 정부가 향후 5 년간에 걸 쳐 이행해야 할 내용과 이를 위한 국제사회의 협력 방안을 담은 “아프간 협약”(The Afghanistan Compact)을 체결하였다.

동 협약은 본문과 두 개의 부속서로 구성되어 있 다. 본문에서는 3 개의 주요목표를 담고 있는데 첫째 는 안전(Security), 둘째는 통치(Governance), 법치 및 인권(Governance, Rule of Law, and Human Rights), 셋째는 경제 및 사회개발 (Economic and Social Development)이다. 한편 마약산업 퇴치도 강조되고 있다. 부속서 I 을 통 해 ANDS의 목표를 달성하기 위한 상세한 성 과, 달성 기준 및 시한 등을 설정하고 있으며 부 속서 II 를 통해 아프간 정부와 국제사회는 원조 
의 효율성과 책임성을 높여 나갈 방향을 밝히고 있다.

회의 참석 국가 및 국제기구는 2006년부터 향 후 5 년간 약 105 억불을 지원할 것을 서약하였으며 한국 정부는 향후 3 년에 걸쳐 약 2 천만불을 지원 하기로 약속하였다.

\section{2. 한국정부의 대아프간 원조내용}

한국정부의 본격적인 대아프간 재건지원 사업 은 도쿄 각료회의 결과로부터 시작하였으나 2001.11 아프간 지원을 위한 워싱턴 고위급회담 이후 아프간과 인접국인 파키스탄, 이란 및 우즈베 키스탄에 체류 중인 아프간 난민을 위한 긴급원조 를 실시하였다. 동 긴급원조는 세계보건기구 (WHO) 및 세계식량계획(WFP) 등 국제기구와 Good Neighbors International(GNI)를 비롯한 국제 NGO 등을 통해 시행되었으며 총 1,132 만불 규모의 구호금과 구호품이 지원되었다. 아프가니 스탄에서 소련군이 철수한 이후 미국의 대아프간 테러전 이전까지 우리 정부의 인도적 원조는 간헐 적으로 이루어졌으나 동 기간 중에는 총 59 만불의 미미한 수준에 그쳤다.

우리 정부는 도쿄각료회의에서 서약한 45 백만 불의 효율적인 집행을 위해 원조규모와 경쟁력이 강한 분야를 고려 몇 가지 원칙을 세웠는데 첫째 교육과 훈련, 의료와 보건, IT 등 전후 재건에 필수 적인 프로젝트 사업, 둘째, 인적자원 개발과 특히 아프간정부의 역량강화를 위한 연수생 초청훈련
및 전문가 파견, 셋째, 아프간 정부의 기능과 공공 서비스 능력향상을 위한 국산 기자재 공여, 넷째, 국제사회의 다자간 재건사업을 위한 신탁기금 기 여 및 끝으로 $\mathrm{NGO}$ 지원을 통한 원조 등 공여의 경 로를 다양화하도록 하였다.

본란에서는 2002년 도쿄각료회의 이후 우리정 부가 시행한 원조사업을 중심으로 살펴보고자 한 다. 대아프가니스탄 원조사업은 크게 나누어 프로 젝트원조, 연수생 초청, 전문가 파견, 물자지원, 국 제신탁기금에의 기탁 및 $\mathrm{NGO}$ 지원사업 등으로 분 류되는데 2002 2005년까지의 집행현황을 금액 으로 살펴보면 다음과 같다

\begin{tabular}{l|c|c}
\hline \multicolumn{1}{c|}{ 구 분 } & 지출금액 (천불) & 구성비(\%) \\
\hline 프로젝트 원조 & & \\
\hline - 직업훈련원 & 9,943 & 21.0 \\
\hline - 중앙공무원교육원 & 5,645 & 12.0 \\
\hline - 농촌개발사업(학교17,보건소8) & 4,985 & 11.0 \\
\hline - 이브니시나 병원 & 3,159 & 7.0 \\
\hline - 중앙공무원 IT 센터 & 1,106 & 2.0 \\
\hline - 카불공대 IT 센터 & 2,119 & 4.5 \\
\hline - 이스탈리프 수력발전소 & 3,010 & 6.0 \\
\hline 연수생 초청 & 2,261 & 5.0 \\
\hline 전문가 파견 & 137 & 0.5 \\
\hline 물자지원 & 7,207 & 15.0 \\
\hline 아프간재건신탁기금 & 6,413 & 13.0 \\
\hline NGO 활동지원 & 1.581 & 3.0 \\
\hline 합 계 & 47,566 & 100 \\
\hline
\end{tabular}

2006년에도 대 아프간 지원 런던 각료급회의에 서 우리 정부가 약속한 바에 따라 아프간에 대한 원조는 계속되며 원조액은 194만불 규모이며 프로 젝트 사후관리비에 1 백만불, 연수생초청(40명)에 
24만불, 전문가 파견(2명)에 3 만불, 물자지원에 37 만불 및 기타 비용 등으로 구성되고 있다.

우리 정부의 원조사업을 유형별로 그 현황과 실 적 및 앞으로 원조사업을 수행하면서 고려해야 할 문제점 등을 살펴보면 다음과 같다.

\section{가. 프로젝트 사업}

1) 현황

직업훈련원 건립

- 공기 : 2003.11.27 2005.6.30

- 대지 : 51,000 평방미터 건평 : 9,993 평방미터(기숙사 포함)

- 건축, 컴퓨터, 전기, 배관, 자동차, 봉제 등 6 개 공과로서 연간 400 명 훈련

- 중앙공무원 교육원 건립

- 공기 : 2005.4.1 2006.12.4

- 대지 : 118,046 평방미터, 건평 : 7,823 평방미터

- 연중 공무원을 교육 훈련시킬 수 있는 장소 로서 연간 400여 명 교육 예상

- 농촌개발 사업의 일환으로 카불 외곽 지역에 학교 14 동 건립

- 공기 : 2003. 1.5 2004.7.25

- 학교 규모 : 교실 $10 \sim 12$ 개

- 동 학교는 비품일체를 갖추어 건립과 동시 인도되어 주재국 에서 관리, 운영

- "이브니시나" 병원 신축 및 기존 병동 개량 및 보수”
- 공기 : 2003. $8.22 \sim 2004.7 .19$

- 대지 : 1,375 평방미터

건평 : 2,765 평방미터

- 병상 2 개, 일반적인 외과수술 장비를 모두 갖춘 응급 환자진료 병원

- 농촌개발 사업의 일환으로 카불외곽 지역에 학교 3동 건립

- 공기 : 2004.11.10 2005.9.30

- 대지는 일정하지 않으나 건평은 1,092 평방미 터, 교실 12 개와 비품일체를 갖춘 학교로 준 공과 동시 주재국에 인도되어 관리되고 있음

- 농촌개발 사업의 일환으로 카불외곽 지역에 보 건소 8 동 건립

- 공기 : $2003.1 .5 \sim 2004.7 .25$

- 대지는 일정하지 않으나 건평은 245 평방미 터로서 간이 진료 시설을 갖춤

- 중앙공무원 IT 센터

- 공기 : 2003.9.18 2004.1.31

- 아프간 중앙행정개혁 및 인사위원회 소속 건 물의 개량 및 보수를 통해 컴퓨터 및 인터넷 설치, 연간 약 1,500 명의 공무원을 훈련

- 카불공대 IT 센터

- 공기 : $2005.2 .20 \sim 2006.3 .15$

- 공대 캠퍼스내 건평 978 평방미터의 훈련원, 컴퓨터 95대 및 인터넷설치로 공대생을 위한 IT 교육장소

n "이스탈리프" 소형 수력발전소 건설

- 공기 : 2005.4.10 2006.10.4

- 카불시 외곽 북부지역의 이스탈리프 계곡에 
서 흐르는 물의 낙차를 이용한 소형 발전소 로서 $200 \mathrm{kw}$ 의 전력을 생산, 인근 마을 620 여 가구에 전기를 공급

이브니시나 병원과 3 개의 보건소는 GNI가 $\mathrm{KOICA}$ 의 위임을 받아 사후관리를 잘 해 나가고 있으며 직업훈련원도 한국산업인력공단이 KOICA 의 지원하에 공과별로 전문가를 파견, 자문 및 운 영을 실시하고 있으며 주재국이 사후관리 능력을 확보하는 대로 완전히 인도할 방침이다.

현재 시공 중이며 2006년 12 월 준공예정인 중 앙공무원 교육원과 2006년 10월 준공예정인 이스 탈리프 소수력발전소도 주재국이 관리능력을 갖출 때까지 우리 측에서 사후관리를 맡아 운영하면서 경영 및 운영기술을 전수할 계획이다.

또한 공무원 IT 센터는 사후관리를 통해 아프간 정부에 인도되어 아프간 정부가 자체적으로 잘 운 용하고 있으며 카불공대의 IT 센터도 우리가 사후 관리를 하고 있으나 대학 측이 자립 운영할 수 있 을 시기에 이를 완전 인도할 계획이다.

\section{2) 평가 및 고려사항}

프로젝트 사업은 위에서 설명한 바와 같이 의 료, 교육, IT 및 에너지 분야 등 여러 분야에 걸쳐 지원을 하였으며 아프간 정부와 국민들은 한국의 프로젝트 사업의 품질과 효과를 매우 높게 평가하 고 있다. 그 이유로는 우선 기술수준이 높은 우리 건설회사가 발주처인 $\mathrm{KOICA}$ 의 감독하에 시설의 설계, 건축 및 감리를 맡았고 장비도 한국 내에서
사용하는 수준으로 갖추었기 때문에 시설 면에서 우수한 것으로 평가되고 있다.

프로젝트 사업의 특징은 사업을 운영할 수 있는 행정능력과 시설과 기자재를 유지하고 보수 및 운 용할 수 있는 관리 및 기술능력을 갖추어야 하며 또한 이에 따른 비용의 부담도 수반되는 문제점이 있다. 당초 프로젝트 지원 사업을 계획하면서 동 분야를 간과한 결과 사업을 시행하는 과정에서 문 제점을 발견하고 이를 보완하기는 하였으나 향후 프로젝트 사업은 기획 단계서부터 사후관리를 포 함, 검토해야 할 것으로 판단된다.

특히 프로젝트 사업은 규모가 커 비용이 많이 들어갈 뿐만 아니라 수원국 입장에서는 이후 자력 으로 여사한 동종 사업을 수행할 시 benchmarking을 할 수 있는 본보기가 될 수 있어야 한 다. 원조국 입장에서는 원조국의 제반 기술수준을 포함한 산업문화의 전반적인 모습을 보여 주는 좋 은 상징이 되기 때문에 국가 이미지와도 깊은 관계 가 있다고 할 수 있다. 원조국 입장에서는 단순히 수원국의 어려움을 덜어 준다는 원조의 개념을 넘 어 수원국에 원조국가의 좋은 이미지를 심어 신뢰 를 얻도록 함으로써 수원국 국민들이 원조에 대한 고마운 마음과 동시에 선진 원조국의 발달된 여러 형태를 스스로 배우려 노력하는 분위기를 만들어 야 한다.

따라서 프로젝트 원조사업은 원조국과 수원국 간 정부 간 협력은 물론 민간분야에서도 상호 신뢰 와 협력을 증진시킬 수 있게끔 장기적인 협력증진 의 관점에서 시설의 구조나 장비 및 건설과 사후관 
리에 있어 세심한 배려를 통한 양질의 상품을 만들 도록 노력해야 한다.

또한 프로젝트 사업수행에 있어 사후관리를 제 외할 경우, 아프가니스탄과 같이 정부 재정도 외국 원조에 의존하고 교육과 기술수준이 극히 빈약한 국가는 정부가 자체적으로 이를 관리할 능력이 없 기 때문에 양질의 시설과 장비가 방치되거나 제대 로 운영이 되지 못하는 결과를 야기할 뿐만 아니라 사후관리를 주로 국제 NGO 등에 위탁하고 있다. 물론 국제 NGO가 이를 잘 관리할 수도 있기 때문 에 수원국 입장에서는 어느 정도 원조의 목표를 충 족할 수 있겠으나 위에서 언급한 바와 같이 수원국 과 원조국간에 우의와 신뢰를 바탕으로 한 장기적 인 협력증진을 기한다는 측면에서는 원조국가의 원조단체 또는 $\mathrm{NGO}$ 가 직접 관리하는 것이 효과적 일 것으로 사료된다.

이에 대한 예로서 우리정부의 의료시설 지원 사 업인 카불시의 “이브니시나" 병원과 카불시 근교 에 8개의 보건소를 건립하였다. 병원과 보건소를 모두 완공 후 주재국에 인도하였으나 주재국이 이 를 관리할 능력이 부족하여 우리 정부에 사후관리 까지 지원을 요청하게 되었다. 우리 정부는 원조계 획에 사후관리는 반영되지 않았기 때문에 이에 대 한 재검토 작업을 하게 되었고 이러한 과정에서 주 재국 정부는 지방의 의료지원이 시급한 점을 고려 하여 동 보건소 관리를 희망하는 외국인 $\mathrm{NGO}$ 에 보건소 8 개 중 5 개의 사후관리를 위탁하게 되었 다. 현재 한국의 $\mathrm{NGO(이웃사랑회)가} \mathrm{병원과} \mathrm{나머}$ 지 3 개 보건소를 한국국제협력단의 위임을 받아
관리하게 되어 한국정부에 의한 원조사업의 이미 지를 계속 이어가고 있으나 외국인 $\mathrm{NGO}$ 의 관리 하에 있는 5 개의 보건소는 한국이 지원한 원조사 업의 이미지를 점차 잃어가고 있는 실정이다.

\section{나. 연수생 초청}

\section{1) 현황}

2002 2005년까지 공공행정, 행정발전, 경제 개발정책, 병원관리, 컴퓨터 교육. 전력기술, 무역 및 투자진흥, 폐수 및 하수처리시설 관리, 통계기 법, 결핵관리, 중소개업유성, 고위급 파트너십 과 정 등에 걸쳐 약 470 명을 초청, 훈련을 실시하였 다. 2006 년에도 총 17 개 분야에 걸쳐 약 40 명을 초청, 훈련을 실시할 계획이다.

특히 고위급파트너 과정은 아프간의 차관 및 주 지사 들이 다수 참석하여 중앙행정은 물론 지방행 정 발전에 있어 고위공무원 리더십의 중요성을 깊 이 인식하는 계기가 되었다.

\section{2) 평가 및 고려사항}

동 훈련에 참가한 사람들은 대부분이 아프간의 중앙행정기관 공무원으로서 개발도상과정에 있어 공무원의 역할이 얼마나 중요한지 한국의 개발경 험 사례를 통해 느끼게 되고 전문지식과 경험도 전 수 받게 되었다.

훈련에 참가한 공무원들은 부존자원이 없는 한 국이 짧은 기간에 이룩한 민주주의와 눈부신 경제 사회발전에 크게 감명을 받은 나머지 아프간의 개 
발모델은 한국이 되어야 한다는 인식을 갖게 되었 다. 특히 고위급 파트너십에 참석한 아프간 정부 고 위인사들을 통해 주재국 정부 최고위층에 이르기까 지 한국의 발전상이 깊게 알려지게 되고 아프간의 발전전략에 많은 교훈을 주게 된 것으로 평가된다.

2005년 말에는 한국을 연수프로그램에 참여한 사람들로 $\mathrm{KOICA}$ 동창회를 결성하기로 원칙적인 합의를 보았으며 주재국의 정세가 호전 되는대로 동창회를 구성, 한-아프간 우호 및 협력증진에 가 교역할을 할 수 있을 것으로 기대된다.

연수 실시를 함에 있어 아프가니스탄 연수생만 을 대상으로 한 국별 프로그램이 있고 전 세계 국 가를 대상으로 한 프로그램에 아프간 연수생을 포 함시키는 일반 프로그램이 있는데 개도국 간에도 발전의 차이가 크고 특히 오랜 내전으로 행정 및 일반 기술 수준이 극히 낮은 아프가니스탄과 같은 국가를 위해서는 가능한 한 국별 프로그램을 마련, 연수기간도 늘리는 등 배려가 있으면 연수 효과도 한층 높을 것으로 사료된다.

\section{다. 전문가 파견}

1) 현황

2002 2006년간 상하수도 관리, 보건 및 의료, 수질관리, 경제개발 계획, 정보통신 정책 등의 분 야에 총 15 명을 파견하였다

\section{2) 평가 및 고려사항}

전문가 파견을 통해 한국의 개발 경험을 전수
하고 기술적인 분야에 대한 심도 있는 교육과 자문 을 실시함으로써 아프간의 관련분야 전문가를 양 성하는데 크게 기여하였다. 전문가 파견은 연수생 초청의 경우 보다는 소수의 인력을 비교적 장기간 파견할 수 있고 다수 인원을 대상으로 교육 및 자 문을 할 수 있기 때문에 교육과 자문에 상대적으로 기간이 많이 소요되는 분야에 적합하다.

아프가니스탄의 경우 연수생 초청의 경우와 마 찬가지로 주재국의 행정 및 전문 기술 분야의 수 준이 타 개도국에 비해 낮기 때문에 전문가 파견 도 보다 장기간으로 하고 특히 정부의 정책 입안 과정에 대한 협력을 요청하고 있음에 비추어 경제 및 사회개발 등 정책분야에 대한 전문가 파견은 우리 정부의 정책입안에 자문을 해온 한국개발원 (KDI)나 한국산업연구원(KIET) 등의 경험 있는 인사를 전문가로 파견하는 것이 바람직하다. 이러 할 경우 주재국 정부 또는 유관기관과 우리 연구 소간에 보다 장기적이고 유기적인 협력관계가 형 성되어 양국 정부 간 협력 증진에도 크게 도움이 될 것이다.

\section{라. 물자지원}

\section{1) 현황}

인도적 지원으로 의약품 등 긴급 구호물품, 교 육용 기자재, 공무원 출퇴근용 차량, 정부 사무실 의 사무기기 등 많은 종류의 국산물품을 지원하였 다. 국산물품 지원의 경우 가능한 한 양질의 물품 을 공급하고자 노력했다. 


\section{2) 평가 및 고려사항}

물자지원은 행정 인프라가 극히 열악한 아프가 니스탄에서는 우선적으로 지원 요청되는 원조분야 로서 특히 사무기기 및 운송수단을 각 행정부처에 원조한 결과 아프간 행정의 인프라를 확충하는데 크게 기여하였을 뿐만 아니라 국산품의 우수한 품 질의 홍보효과도 거양하였다.

물자지원의 경우 차량이나 일반 전기제품 등 현 지에서 수리가 가능한 경우는 문제가 없으나 고급 기술을 요하는 기자재의 경우 고장 시 수리를 하는 문제를 사전에 검토 - 대책을 세워야 한다. 공항 및 일부 청사건물의 보안 감식 장비를 지원하고 고장 시 수리를 위해 기술자 훈련도 시켰으나 현지인에 의한 수리가 불가능하여 수차에 걸쳐 우리 전문가 가 출장 - 수리를 한 경우가 있다.

이러한 문제점을 해결하기 위해서는 기계의 작 동방법 및 수리 등에 관한 지침서를 반드시 영문으 로 준비하고 교육자와 피교육자 간에 항상 커뮤니 케이션이 이뤄질 수 있도록 연결을 맺어 주는 것이 중요하다. 교육자가 이를 위해 통상적으로 고객에 게 추가적인 노력을 기울인 경우 보상도 고려해야 할 것이다.

\section{마. 신탁기금 및 $\mathrm{NGO}$ 를 통한 원조}

정부가 $\mathrm{KOICA}$ 를 통해 직접 시행한 이상의 주요 원조사업 외에 정부는 아프간 개발 신탁기금에 641만 불을 기탁함으로써 국제사회의 아프간에 대 한 공동원조 프로젝트에도 참여하였다. 또한 우리
$\mathrm{NGO}$ 를 통해 아프간의 난민구호, 교육, 보건 및 의 료, 지역개발 분야 등 총 36 개 사업에 약 158 만불 을 지원함으로써 우리 $\mathrm{NGO}$ 의 해외 협력사업 역량 을 강화하는데도 기여하였다.

\section{3. 대 아프가니스탄 원조의 문제점 및 고려사항}

\section{가. 테러리즘과 원조}

아프가니스탄은 테러와의 전쟁이 계속되고 있 으며 알카에다/탈레반 등 테러단체의 우선 공격목 표가 외국군, 아프간 군과 경찰 및 고위 정부공무 원을 포함한 아프간 정부, 외교관과 외국원조기관 원, 아프간 정부와 외국군 및 기관에 협조하는 자 및 NGO 등으로 특히 외국원조기관에 종사하는 사 람이나 원조 프로젝트를 수행하는 모든 사람들이 테러의 공격 대상이 되고 있다.

외국원조기관 뿐만 아니라 아프간 내에서 활동 하는 민간 기업을 포함한 모든 사람들이 테러리스 트들의 우선적인 공격대상이 되기 때문에 원조활 동에 있어서 안전 확보가 우선적으로 고려되어야 한다. 주재국 정부가 외국정부의 원조기관 뿐만 아 니라 국제 $\mathrm{NGO}$ 에 대한 안전 확보 지원을 위해 노 력하고 있으나 낮은 보수와 열악한 장비로 경찰의 사기가 낮기 때문에 경찰의 적극적인 협조를 얻기 위해서는 자체적으로 상당부분, 사실상 전액의 비 용을 부담해야 하는 실정이다.

따라서 원조사업 시행과정에 참여하는 인력은 물론 및 시설과 장비 및 자재 등 전반을 보호하기 
위한 안전계획을 처음부터 원조계획의 주요 부분 으로 검토하고 포함시켜야 한다. 아프간에는 이에 대한 보험제도가 미비하고 외국 보험회사에 가입 할 경우 거절당하거나 과도한 보험료를 요구하기 때문에 가입의 실익이 적다. 원조사업에 투입되는 물자의 구입이나 건설 용역비 등 일체의 비용은 정부의 예산이며 이는 국민의 세금이기 때문에 부 실한 관리는 정부의 국민에 대한 책임문제로 연결 된다.

따라서 원조사업은 사업과 안전 확보가 병행되 어 진행되어야 하며 보다 확실히 말한다면 안전 확보 계획이 원조사업계획에 필수불가결한 요소 로서 반영되어야 한다. 아프가니스탄 뿐만 아니 라 대부분의 수원국이 테러리스트들의 위협으로 어려움을 당하고 있고 이러한 현상은 오히려 증가 하고 있는 추세임을 감안 원조정책 수립에 있어서 안전 확보 문제에 보다 비중을 두고 다루어 나가 야 할 것이다.

\section{나. 원조규모의 증대}

아프가니스탄에 대한 원조와 관련 위에서 설명 된 바와 같이 도쿄각료회의에서는 국제사회의 서 약한 액수의 $1 \%$ 에 해당하는 금액을 지원약속 하 였으나 베를린 회의와 런던회의에서는 아프가니 스탄과 국제사회의 기대에 훨씬 미치지 못한 지원 내용을 발표하게 되었다. 이는 우리 정부가 아프 가니스탄에 대한 지원의 중요성을 인식하지 못해 서가 아니라 연간 사용할 수 있는 원조예산의 제
약 때문이다.

공적원조 규모는 한 나라의 대외 역할과 직접적 인 관련이 있는바 우리나라가 $\mathrm{OECD}$ 회원국이며 우리 경제의 대외경제의존도는 70 80\%, 우리의 경제규모는 세계 191 개 유엔회원국 중 11 위를 차지 하고 있다. 이러한 가운데 현재 우리의 공적원조 예산규모는 2005년 국민소득(GNI)기준 $0.094 \%$ 밖에 되지 않고 있어 같은 해 $\mathrm{OECD}$ 국가 평균 $0.25 \%$ 에 비해 지나치게 낮은 수준이다.

아프가니스탄과 국제사회는 한국이 세계 10 위 권의 경제대국이며 기술수준과 1 인당 국민소득 수 준 등에 비추어 더 많은 기여를 할 수 있을 것으로 기대가 크다. 특히 아프가니스탄은 한국의 발전상 이 동국의 발전모델이 되기를 바라고 있어 한국과 의 정부 간 협력은 물론 민간분야에서의 협력 증대 를 강력히 희망하고 있음에 비추어 공적원조의 증 대를 통한 민간분야의 협력도 크게 기대할 수 있는 국가이기도 하다.

\section{다. NGO 활동과 연계 강화}

현재 아프가니스탄에는 동서문화교류협회 (ECC), 이웃사랑(GNI), 한민족복지재단(KFWA), 아시아문화개발협력기구(IACD), Global Care for Afghanistan, Harvest Korea, 개척자들, 선한사 람들 등 한국 NGO 소속원 80 여명이 봉사활동을 하고 있으며 그 외 다국적 $\mathrm{NGO}$ 에 근무하는 사람 도 20 여명에 이른다. 또한 일부는 가족을 동반하 고 있어 가족까지 합하면 $\mathrm{NGO}$ 에 종사하는 한국인 
인력은 약 130 명에 달하고 있다.

우리 $\mathrm{NGO}$ 는 그 간 봉사활동을 통해 주재국 국 민들과 친밀하고 깊은 협력관계를 유지해 오고 있 으며 현지어를 잘 구사하는 사람들도 있다. 대부분 이 3 5년간 이 곳에서 장기간 봉사해 온 사람들이 고 길게는 8 여 년간을 계속 생활해 온 인사도 있기 때문에 한국 $\mathrm{NGO}$ 의 아프간에 대한 지식과 경험은 높이 평가된다.

정부가 공적원조를 $\mathrm{NGO}$ 와 협력하여 시행할 경 우 여러 가지 장점이 있다. 첫째로 $\mathrm{NGO}$ 요원들의 장기 근무로 축적한 주재국에 대한 이해 및 원조사 업에 대한 전문지식과 경험을 활용할 수 있으며, 둘째로는 정부의 원조자금과 $\mathrm{NGO}$ 의 matching fund를 활용할 경우 프로젝트 당 원조규모를 늘일 수 있어 원조의 효과를 높일 수 있다. 셋째로 NGO 는 현지 NGO 및 기타 현지인을 활용한 경험이 많 기 때문에 KOICA 사무소의 제한 된 인력으로 사 업을 수행하기 어려운 원격지 또는 오지 등에 대한 사업을 원활히 할 수 있다. 넷째로 $\mathrm{NGO}$ 의 활동 규 모와 범위의 확대는 $\mathrm{NGO}$ 의 역량증대를 가져와 결 과적으로는 우리 국민의 해외 진출을 촉진하고 직 간접적으로 우리 기업의 해외진출에도 많은 도움 을 줄 수 있다.

$\mathrm{NGO}$ 활동이 반드시 장점만 있는 것은 아니다. $\mathrm{NGO}$ 소속원들이 특정 종교단체에 소속되어 동 단 체의 요구에 의해서나 자발적으로 봉사활동 외 선 교 활동 등을 겸하여 현지인과 마찰을 빚게 될 경 우 이를 지원한 정부는 딜레마에 빠질 수도 있다. 따라서 정부가 $\mathrm{NGO}$ 와 원조사업을 협력하여 시행
할 경우, 또는 $\mathrm{NGO}$ 사업에 대해 자금만 지원할 경 우에도 이러한 부정적인 결과가 발생하지 않도록 계약단계에서부터 사업이 완료될 때까지 지도와 감독을 병행해야 할 것이다.

그 간 아프가니스탄 원조사업을 위해 국내 $\mathrm{NGO}$ 에 대한 지원은 2002 2003 간 36개 사업에 150 만불 상당이 되나 아프간의 정세 악화와 원조 자금의 부족 등으로 그 이후 지원을 못하고 있는 실정이다.

\section{라. 문화 및 스포츠 분야 등 원조의 다변화}

위의 원조사업 실적에서 보는 바와 같이 우리 정부의 원조사업은 문화 및 스포츠 분야가지 보다 넓게 시행되지 못하고 있다. 각 국의 원조정책은 수원국의 수요, 원조국의 대외정책, 공급분야의 경 쟁력 등 제반 고려사항을 반영하여 결정되기 때문 에 우선순위가 국가에 따라 다소 차이가 있게 마련 이다.

대외정책에 있어 국가의 이미지 제고는 점차 그 중요성을 더해 가고 있으며 특히 문화 및 스포츠를 통한 국가 이미지제고는 매우 효율적인 방법으로 인식되고 있다. 21 세기를 "문화의 시대"라고 흔히 일컫는 이유도 문화의 중요성이 강조되기 때문일 것이다. 한국 경제의 대외 의존도 심화는 물론 연 간 1천만 명이 해외여행을 하는 등 국민생활도 그 무대를 전 세계로 향해 계속 높여 가고 있음에 비 추어 우리 국가의 이미지 고양문제는 중요성을 더 해 가고 있다. 따라서 원조에 있어서도 동 분야에 
대한 관심을 보다 높여야 할 것으로 보인다.

스포츠 협력과 관련, 아프가니스탄에 태권도 진 흥을 도왔으면 하는 의견이다. 우리나라가 태권도 종주국이고 주재국이 국제 경기에서 메달을 따는 유일한 종목도 태권도이며 전국적으로 광범위하게 인기를 얻고 있는 종목으로서 태권도 인구가 3 만 여명을 헤아림에도 불구하고 태권도를 배운 인사 들이 외국 정부가 지원하는 태권도와 유사한 무술 종목으로 변신하여 도장을 열고 있는 현실을 볼 수 있다.

\section{마. 원조의 효율성 제고}

아프가니스탄에 대한 원조와 관련 주재국 정계, 정부 및 일반국민들이 갖는 가장 불만은 원조사업 에 있어 효율성이 떨어진다는 점이다. 테러와의 전 쟁을 치르고 있는 안전이 취약한 곳이기 때문에 선 진 외국기업의 진출이 거의 없고 주재국 기업의 경 우 기술력이 떨어진 결과 다수 원조사업이 외국 $\mathrm{NGO}$ 들에 의해 추진되고 있는 실정이다. 외국 $\mathrm{NGO}$ 는 인접국에서 진출한 기업에 하청을 주고 동 기업은 또 다시 현지 기업에 하청하는 방식으로서 이 과정에서 $\mathrm{NGO}$ 들이 많은 몫을 차지한 결과 부 실한 사업이 된다는 주장이다.

이를 개선하기 위해 주재국은 외국정부의 원조 를 가급적 아프간정부를 통해 실시할 것을 요청하 면서 $\mathrm{NGO}$ 의 활동 분야 중 건설업은 제외하기로 결정하였으나 원조국 정부의 협조가 없는 한 이행 에 많은 어려움이 있을 것으로 보인다. 다행히 우
리나라의 원조는 앞서 언급한 바와 같이 우리 진출 기업이 이를 수행한 결과 주재국의 불만을 사지 않 게 되었고 결과적으로 원조금액의 누수현상 없이 양질의 원조 상품을 제공할 수 있었다.

그럼에도 불구하고 아프간 정부나 국민들은 외 국원조사업에 대한 불신이 커 작은 하자에도 예민 한 반응을 보이는 경우가 많기 때문에 원조사업의 질적 수준은 물론 우리의 원조사업이 국제 NGO 등을 통해 이뤄지는 사업과는 달리 대부분의 원조 액이 주재국을 위해 지출된다는 인식을 계속 심어 나가도록 하는 노력이 필요할 것이다.

\section{4. 맺는 말}

아프가니스탄에 대한 원조와 관련 원조형태별 내용, 문제점 및 평가 등에 대한 기술을 해 보았는 데 이상에서 빠진 몇 가지 내용을 추기하면서 결론 에 대신하고자 한다

첫째, 우리정부의 대 아프간 지원과 관련 $\mathrm{KOICA}$ 를 통한 정부의 공적원조사업 외에 중요한 부분으로서 한국군지원단의 파견을 빼 놓을 수 없 다. 한국군지원단 200 여명이 동맹군 소속으로 파 견되어 있으며 이 중 동의부대(의료단)는 2002.2 부터 다산부대(공병)는 2003.2부터 지금까지 카불 북부 지역 $80 \mathrm{~km}$ 지점에 위치한 바그람 공군기지 에 주둔하고 있다. 이들의 주요임무로 공병부대는 동맹군이 사용하는 공군기지의 시설물 건설 및 보 수 등을 담당하고 있으며 동의부대는 동맹군과 현 지주민에 대한 진료를 담당하고 있다. 동의부대의 
주된 진료대상은 인근지역 아프간주민들에 대한 의료봉사활동으로서 그 동안 20 만 명이상의 진료 실적을 보여 현지 주민들로부터 크게 환영을 받고 있다.

둘째, 아프가니스탄뿐만 아니라 특히 프로젝트 형 원조사업을 실시할 경우에 흔히 발생할 수 있는 문제로서 현지 문화, 환경, 관행 등에 충분한 이해 와 사전조사가 필요한 점을 들 수 있는데 자연환경 의 차이로 인해 발생하는 홍수나 기후의 변화가 공 사과정에 주는 충격은 많이 다를 수 있기 때문에 타당성조사를 실시할 경우 보다 면밀한 검토가 필 요하겠다.

일례로 아프간의 경우 산에 나무가 없기 때문에 비가 올 경우 토사 및 돌이 그대로 쏟아져 내려 우 리의 환경과는 전혀 다른 결과를 가져옴을 볼 수 있다. 낮과 밤의 일교차가 심하고 건조한 기후 등 도 공사에 영향을 미친다. 또한 공사장 주변에 대 한 훼손이나 개인 소유물을 침범한 경우나 결과적 으로 손해를 끼칠 우려가 있는 경우 집단성이 강한 주민들의 반응은 일반적으로 개인재산 침해에 대 한 개별적 보상방법 협의와 같은 형태에서 나타나 는 것과 다른 것을 볼 수 있다. 또한 보상절차와 공 사시행을 연계하는 방법도 다른 경우가 있다. 이러 한 의미에서 그간 아프간에서의 프로젝트 원조를 수행하면서 쌓은 경험과 시행착오 등이 잘 축적되 어 다른 지역에서의 프로젝트 원조 시 활용될 수 있을 것으로 본다.

셋째, 아프가니스탄과 같이 법제가 미비한 국가 에서는 분쟁이 발생할 경우 관련법규를 찾기가 어
렵고 적용에 있어 현실성이 떨어지는 경우도 많으 므로 계약서가 가장 중요한 역할을 하기 때문에 계약내용은 가능한 한 세세한 분야에 걸쳐 상세해 야 한다. 또한 공사에 지장을 주는 불법 시설물이 있다하더라도 법치주의가 잘 이행되지 않는 수원 국 정부가 이를 쉽게 철거할 수 없는 경우가 많기 때문에 원조사업 타당성 조사 시부터 이러한 문제 도 보다 심도 있게 연구되고 계약체결 이전에 해 결방안이 이해당사자간에 구체적으로 합의되어야 한다.

넷째, 그간 아프간에 지원한 원조는 모두 무상 원조였으나 정부는 원조예산의 제약으로 2006년 런던회의 시 유상 및 무상원조 2 천만불 공여를 약 속했다. 그러나 주재국의 재정형편상 중단기적으 로는 대외채무변제를 기대하기가 어려운 실정이이 며 장기적으로 아프가니스탄에 대한 경제전망이 여타 최빈국의 예와 같다고는 할 수 없으나 그간 국제사회가 대부분의 최빈국에 지원한 유상원조는 Paris Club 회의 등 다자간 협의나 기타 양자 간 협의를 통해 탕감되어온 게 사실이다.

또한 아프가니스탄의 국토 및 인구를 고려 1천 만불 규모의 연성차관으로서 지원할 수 있는 사업 을 찾기가 어려우며 우리나라의 $\mathrm{EDCF}$ 차관의 조 건에 비추어 수원국의 적극적인 호응도 얻기기 쉽 지 않다. 따라서 원리금 회수가 불확실하고 아프가 니스탄에 대한 경제적 기여도 크게 기대하기 어려 운 유상원조보다는 규모를 조정하는 한이 있더라 도 가능한 한 무상원조 형태로 지원하는 것이 효과 적일 것으로 기대된다. 
다섯째, 원조사업을 시행하는 과정에서 우리기 업의 투자진출을 함께 고려함도 좋을 것으로 사료 된다. 우리기업이 관심을 갖고 있는 투자분야에 대 한 타당성 조사 치안사정 악화를 고려한 투자금액 에 대한 보험 등 기타 우리기업의 투자를 촉진 및 지원할 수 있는 분야에 대한 원조를 우선적으로 시 행하는 방법도 고려할 수 있는데 이를 위해서는 $\mathrm{KOICA}$ 의 연구기능을 보다 강화하여 국별 투자에 관심 있는 기업을 찾고 이들 기업과 원조 및 투자 사업에 관한 협의 메카니즘을 만드는 것도 고려해 볼 만 하다. 저개발국가에 대한 공적원조 증대가 바람직하기는 하나 원조예산 규모를 늘리는데 많 은 제약이 있고 작은 규모의 원조에 의한 개발효과
보다는 민간기업의 투자진출을 통한 효과가 큼을 감안해야 한다.

끝으로 원조사업은 그 자체가 어려운 아프가니 스탄에 도움을 주는 것으로서 가급적 많은 양의 원 조를 통해 아프가니스탄을 지원하는 것이 중요하 기는 하나 원조예산의 제약 때문에 쉽지가 않다. 대신 원조가 우리의 국가이미지를 높인다는 관점 에서 양질의 원조 상품을 제공하도록 하여야 하며 이를 위해 프로젝트 타당성 조사에서 빠진 문제점 을 보완하거나 환경과 기타 사정으로 인해 불가피 하게 공기를 조정하고 또는 설계를 변경해야 할 경 우 작은 규모의 예산 절약을 이유로 이에 인색해 하는 일이 없어야 할 것이다. 